\title{
Strategi Penanaman Karakter pada Anak Usia Sekolah Dasar di Kota Jayapura
}

\section{Didik Efendi}

${ }^{1}$ IAIN Fattahul Muluk Papua, Kota Jayapura, Indonesia

*Corresponding author: didik.kotjap@gmail.com

\begin{abstract}
The heterogeneous environment greatly affects students' character. Many tribes, cultures, religions and other differences will cause many problems to the students' aqeedah and akhlaq. To prevent the negative influence of the environment early steps are increasing characterto the children. This embedment will protect the children from a condensive lesson. This research aims to describe the strategy of character embedment in students at SDIT Permata Hati in Jayapura. This research employs qualitative approach using case study design. The data collection techniques are interview, observation, and documentation. The data analysis techniques include data reduction, data presentation and conclusion making. The data validity checking is performed trough triangulation by using various sources and methods. The research results indicate that the embedment strategies of character in students of SDIT Permata Hati are, (1) planning of the learning process, daily life activities, relationships with parents and school's programs; (2) $d$, the implementation which comprises of strategies of learning, habituation, exemplary, and partnership: (3) evaluation which includes observation and measurement of the planning and implementation that have been carried out, and follow up the improvement or development of the school's programs. Then the results are then reported to the principal and parents.
\end{abstract}

Keywords: embedment strategies; character; students

\section{ABSTRAK}

Salah satu yang mempengaruhi karakter anak adalah lingkungan yang plural. Dengan banyaknya perbedaaan suku, budaya, agama dan lainnya akan menimbulkan berbagai masalah dalam penanaman karakter anak. Untuk mencegah dampak negatif dari lingkungan yang plural, maka perlu adanya penanaman karakter sejak dini. Penelitian ini bertujuan untuk mendeskripsikan strategi penanaman karakter pada anak di SDIT Permata Hati Jayapura. Penelitian ini menggunakan metode kualitatif dengan rancangan studi kasus. Teknik pengumpulan data meliputi wawancara, observasi dan dokumentasi, sedangkan teknik analisis datanya dengan reduksi data, penyajian data dan pengambilan kesimpulan. Pengecekan keabsahan data dilakukan dengan triangulasi dengan menggunakan berbagai sumber dan metode. Informannya kepala sekolah, wakil kepala sekolah, guru, wali murid dan peserta didik. Hasil peneltian menunjukkan bahwa strategi penanaman karakter di SDIT Permata hati Jayapura dilakukan melalui tiga tahap, (1) Planning. Planning merupakan keseluruhan proses pemikiran penentuan semua aktifitas yang akan dilakukan dalam menanamkan karakter kepada siswa; (2) Actuating. Dalam melaksanakan perencanaan dalam proses penanaman karakter pada siswa SDIT Permata hati dengan menggunakan strategi pembelajaran, pembiasaan, keteladanan dan kemitraan; (3) evaluation Tahap langkah terakhir pelaksanaan dalam penanaman karakter dievaluasi keberhasilannya.

Kata Kunci: anak; karakter; strategi penanaman

\section{Pendahuluan}

Masyarakat Indonesia terkenal dengan karakternya yang sopan santun dalam berperilaku, mengedepakan musyawarah mufakat dalam menyelesaikan masalah, toleransi antar umat beragama, gotong royong. Ada 18 karakter yang menjadi ciri khas bangsa ini, yakni; religius, jujur, toleransi, disiplin, kerja keras, kreatif, mandiri, demokratis, rasa ingin tahu, semangat kebangsaan, cinta tanah air, menghargai prestasi, bersahabat/ komunikatif, cinta damai, gemar membaca, peduli lingkungan, peduli sosial dan tanggung jawab. Namun kini, karakter tersebut semakin hari semakin punah. Bila kita amati banyak perilaku yang tidak 
sesuai dengan karakter bangsa telah menghiasi di negera Indonesia. Tidak sedikit dari jajaran pemerintahan sampai rakyat jelata telah melakukan perilaku yang menyimpang dari karakter bangsa, seperti halnya korupsi, tawuran antar pelajar, pembunuhan, pemerkosaan, pencurian dan lain sebagainya. Perilaku-perilaku tersebut seolah-olah sudah menjadi karakter masyarakat sekarang.

Keprihatinan atas masalah karakter menjadi keprihatinan secara nasional. Untuk menjawab tantangan diatas, maka pada tahun 2013 pemerintah mengeluarkan kurikulum baru yang sebagaimana terlampir dalam Permendikbud No. 67 tahun 2013, yang disebut kurikulum 2013. Kurikulum 2013 lebih ditekan pada pendidikan berbasis karakter dan kompetensi dengan tujuan untuk meningkatkan mutu proses dan hasil pendidikan yang mengarah pada pembentukkan budi pekerti dan berakhlak mulia peserta didik secara utuh, terpadu, seimbang sesuai standar kompetensi lulusan pada setiap satuan pendidikan.

Presiden pertama kita, Ir. Sukarno menegaskan bahwa "Bangsa ini harus dibangun dengan mendahulukan karakter (character building), karena character building inilah yang akan membuat Indonesia menjadi bangsa yang besar, maju dan jaya serta bermartabat. Kalau character building ini tidak dilakukan, maka bangsa Indonesia akan menjadi bangsa kuli"(Samani \& Hariyanto, 2013). Presiden Sukarno menganggap pendidikan karakter sangat penting untuk kemajuan zaman apalagi pada zaman yang karakter bangsa dijajah secara tidak langsung. Senada dengan Presiden Sukarno, Presiden ke 6 bapak Susilo Bambang Yudhoyono juga menyampaikan pesan pembangunan watak (character building) amat penting. Kita ingin membangun manusia Indonesia yang berakhlak, berbudi pekerti dan berperilaku baik. Bangsa kita bangsa kita ingin pula memiki peradapan yang unggul dan mulia. Peradapan ini dapat kita capai apabila masyarakatnya kita juga merupakan masyarakat yang baik (good society) (Samani \& Hariyanto, 2013).

Karakter bukan hal yang diwariskan, tetapi karakter sesuatu yang dibangun secara berkelanjutan atau berkesinambungan dari waktu ke waktu melalui pemikiran dan perbuatan. Pendidikan karakter adalah salah satu alat yang dapat digunakan untuk membangun karakter bangsa. Pendidikan karakter merupakan upaya dalam menanamkan nilai-nilai karakter kepada siswa baik secara langsung maupu tidak langsung. Untuk menanamkan nilai-nilai karakter di sekolah dapat dilakukan berbagai cara tidak hanya terpaku pada buku pedoman atau buku pelajaran.

Pendidikan karakter adalah salah satu pendidikan yang bertujuan untuk mencetak generasi Indonesia yang berakhlak mulia. Karakter merupakan hal yang sangat penting dalam membentuk peradapan bangsa. Keberhasilan suatu bangsa tidak ditentukan oleh banyaknya kekayaan alam suatu negeri, tetapi ditentukan oleh kualitas sumber daya manusianya. Bahkan bangsa yang besar dapat dilihat dari kualitas karakter bangsa (manusia itu sendiri). Pendidikan karakter adalah salah satu pendidikan yang bertujuan untuk mencetak generasi Indonesia yang berakhlak mulia. Untuk itu pendidikan karakter harus diberikan kepada anak sedini mungkin, agar menjadi pondasi atau dasar dalam melakukan sesuatu.

Salah satu faktor yang mempengaruhi karakter anak adalah lingkungan. Lingkungan merupakan tempat anak bermain, tempat bergaul dan tempat mendapatkan pengalamanpengalaman baru dalam hidupnya. Apabila anak berada di lingkungan yang kurang kondusif seperti lingkungan yang didalamnya terbiasa dengan hal-hal yang kurang baik, maka bisa dipastikan kepribadian anak seperti itu juga, karena sifat anak yang suka meniru hal-hal yang 
disenanginya. Lingkungan bisa dibagi menjadi dua, pertama lingkungan keluarga. Lingkungan keluarga sangat mempengaruhi karakter anak. Karena orang tualah yang membersamai mereka dalam lingkungan keluarga serta, sehingga anak akan mereka apa yang ucapkan atau dilakukan orang tuanya setiap hari. Di kota Jayapura, yang masyoritas penduduknya adalah berkarir, terkadang tugas mendidik anak terlewatkan, orang tua hanya berpikir mencari uang dan menyekolahkan anaknya di sekolah yang unggul. Menurut mereka ini adalah salah satu bentuk kepedulian orang tua terhadap anak. Hal tersebut tidak sepenuhnya salah, tetapi seyogjanya orang tua tetap meluangkan waktunya untuk mendidik anak, tidak dilepas atau diberikan sepenuhnya kepada sekolah. Kerjasama antara orang tua dan sekolah akan mempermudah dalam mendidik anak.

Kedua, lingkungan sekitar/ lingkungan pergaulan anak. Lingkungan ini sangat mempengaruhi karakter seorang anak. Dimana di lingkungan inilah anak bergaul dengan siapa saja yang mempunyai karakter berbeda-beda. Kota Jayapura adalah kota yang bisa dikatakan Indonesia mini, dimana Kota Jayapura terdapat berbagai suku, bahasa, agama, budaya dan perbedaan-perbedaan lainnya. Secara garis besar suku yang mendiami di kota Jayapura adalah suku asli warga Jayapura, suku Jawa, suku Bugis, suku Dayak, suku Hamadi, suku Wamena. Selain suku, di kota Jayapura juga terdapat beberapa agama, yakni agama Islam, Kristen Protestan, Kristen Katolik, Budha, dan Konghucu. Setiap suku dan agama mempunyai budaya dan ajaran masing-masing. Semakin banyaknya suku, budaya dan agama, maka semakin banyak pula karakteristik, budaya atau kebiasaan-kebiasaan yang beragam. Banyaknya perbedaaan dalam sebuah kota bisa berdampak positif dan negatif. Dampak positifnya adalah apabila perbedaan dapat dikelola dengan baik, saling menghargai, maka akan menimbulkan kekuatan yang luar biasa namun sebaliknya apabila setiap suku maupun golongan hanya mementingkan golongannya, tidak mau bertoleransi maka akan berdampak perpecahan dan pemusuhan.

Pendidikan karakter bisa terwujud apabila ada kerjasama antara pemerintah, sekolah dan lingkungan keluarga. Sebaik apapun undang-undangnya maupun kurikulumnya kalau tidak didukung dengan sekolah yang berbasis karakter dan peranan orang tua, musthil pendidikan karakter bisa terwujud. Sebaliknya juga sebaik-baiknya program yang ada disekolah tanpa dukungan pemerintah, program hanylah sebatas program. Oleh sebab itu antara pemerintah, sekolah dan orang tua harus sinergi dalam memujudkan bangsa yang berkarakter.

Penanaman secara etimologi berasal dari kata tanam yang artinya menabur benih dan jika kita kaitkan dengan karakter dapat diartikan menaburkan nilai-nilai karakter kepada siswa. Strategi (strategy) berasal dari "kata benda" dan "kata kerja" dalam bahasa Yunani. Sebagai kata benda, strategos merupakan gabungan kata stratos (militer) dengan "ago" (memimpin). Sedangkan sebagai kata kerja stratego diartikan merencanakan (to plan). Dalam artian yang umum strategi adalah suatu tatanan potensi dan sumber daya agar dapat efesien memperoleh suatu rangcangan. Strategi secara umum mempunyai pengertian suatu garis-garis besar haluan untuk bertindak dalam usaha mencapai sasaran yang telah ditentukan (Nata, 2011). Direktorat Pembinaan Sekolah Menengah Atas, Direktorat Jenderal Manjemen Pendidikan Dasar dan Menengah Depdinas, menjelaskan Strategi merupakan usaha untuk memperoleh kesuksesan dan keberhasilan dalam mencapai tujuan. Dalam dunia pendidikan strategi dapat diartikan a plan, method, or series of activities designed to a particular education goal (Mulyono, 2012). 
Ada dua hal yang perlu dicermati dari Strategi yang diartikan sebagai perencanaan yang berisi tentang rangkaian kegiatan yang didesain untuk mencapai pendidikan tertentu, yaitu (1) Strategi merupakan rencana tindakan (rangkaian kegiatan) termasuk penggunaan metode dan pemanfaatan berbagai sumber daya/ kekuatan; (2) Strategi disusun untuk mencapai tujuan. Artinya arah dari semua penyusunan strategi adalah pencapaian tujuan. Dengan demikian, penyusunan langkah-langkah, pemanfaatan berbagai macam fasilitasdan sumber belajar semuanya diarahkan dalam upaya pencapaian tujuan. Oleh sebab itu, sebelum menentukan strategi, perlu dirumuskan tujuan yang jelas yang dapat diukur keberhasilannya, sebab tujuan adalah rohnya dalam implementasi suatu strategi (Sanjaya, 2008).

Karakter menurut KBBI merupakan sifat-sifat kejiwaan, akhlak atau budi pekerti yag membedakan seseorang dengan orang lain. Secara etimilogi karakter berasal dari bahasa Latin character yang berarti watak, tabiat, sifat-sifat kejiwaan, budi pekerti, kepribadiaan dan akhlak. Dalam bahasa arab karakter dapat diartikan khuluq, sajiyyah, thab'u' budi pekerti, tabiat atau watak. Secara terminologi karate berarti sebagai sifat manusia pada umumunya yang bergantung pada factor kehidupannya sendiri. Lebih lanjut Febriyanto, dkk (2020) mengemukakan pendidikan karakter merupakan usaha yang dilakukan seseorang untuk memperoleh pengetahuan tentang pemahaman pribadi yang baik dan tidak baik. Karakter adalah sifat kejiwaan, akhlak atau budi pekerti yang menjadi ciri khas seseorang atau kelompok.

Ada 18 karakter yang harus ditanamkan kepada anak sejak dini, yakni; religius, jujur, toleransi, disiplin, kerja keras, kreatif, mandiri, demokratis, rasa ingin tahu, semangat kebangsaan, cinta tanah air, menghargai prestasi, bersahabat/ komunikatif, cinta damai, gemar membaca, peduli lingkungan, peduli sosial dan tanggung jawab. Untuk menanamkan 18 karakter tersebut tidak bisa terlepas dengan dunia pendidikan. Menurut Lickona (Samani \& Hariyanto, 2013) mendefinisikan pendidikan karakter sebagai upaya yang sungguhsungguh untuk membantu seseorang memahami, peduli dan bertindak dengan landasan ini nilai-nilai etis. Dalam pandangan Lickona (Adisusilo, 2013) pendidikan nilai/ moral yang menghasilkan karakter ada tiga komponen karakter yang baik (components of good character) yaitu moral knowing atau pengetahuan tentang moral, moral feeling atau perasaan tentang mental dan moral action atau perbuatan moral. Ketiga komponen tersebut menujuk pada tahapan pemahaman sampai pelaksanaan nilai/ moral dalam kehidupan sehari-hari.

Likcona menggambarkan ada 11 prinsip pendidikan karakter dapat berjalan baik, yakni (1) kembangkan nilai-nilai Universal/ dasar sebagai pondasinya; (2) definisikan karakter secara komprehensif yang mencangkup pikiran, perasaan dan perilaku yang mencancup pikiran, perasaan dan perilaku; (3) gunakan pendekatan yang komprehensif, disengaja dan proaktif; (4) ciptakan komunitas sekolah yang penuh perhatian; (5) beri peserta didik kesempatan untuk melakukan tindakan moral; (6) buat kurikulum akademik yang bermakna dan yang menghormati semua peserta didik, mengembangkan sifat-sifat positif dan membantu peserta didik untuk berhasil; (8) melibatkan seluruh civitas sekolah sebagai komunitas pembelajaran dan moral; (9) tumbuhkan kebersamaan dalam kepemimpinan moral; (10) libatkan keluarga dan anggota masyarakat sebagai mitra; (11) evaluasi karakter sekolah, fungsi staf sekolah sebagai pendidik karakter dan sejauh mana peserta didik memanifestasikan karakter yang baik (Lickona, 1991). 
Menurut Efendi (2019) usia anak sekolas dasa pada umumnya berkisar 7-13 tahun. Dalam masa perkembanganya mengalami empat perkembangan, salah satunya adalah perkembangan moral. Moral juga sering juga dengan katakter. Pembentukan katakter pada anak usia sekolah dasar melalui beberapa tahap, yakni (1) Receiving (meneima). Pada tahap ini anak menerima pengetahuan tentang nilai-nilai karkater dari guru; (2) Responding ( menanggapi). Pada tahap ini anak mulai menangapi atau memberikan rangsangan afektif yang meliputi compliance (manut), secara aktif memberikan perhatian dan satisfication is respons (puas dalam menanggapi). Tahap ini siswa sudah mulai aktif dalam menanggapi apa yang diberikan oleh guru yang terkait dengan aqidah dan akhlak; (3) acting (bertindak) pada tahap ini anak mengaktualisasikan nilai-nilai karakter dalam keseharianya dengan dibimbing guru; (4) being (mnjadi seperti yang diketahui) pada tahap ini anak secara spotanitas melalukan apa yang dipelajari dan dibiasakan dalam kesehariannya.

\section{Metode Penelitian}

Penelitian ini menggunakan pendekatan kualitatif dengan rancangan studi kasus. Penelitian kualitatif dengan desai studi kasus bertujuan untuk menggambarkan, meringkas berbagai kondisi, berbagai situasi yang ada di SDIT Permata Hati Kota Jayapura yang menjadi obyek penelitian dan berupaya menarik realitas itu ke permukaan sebagai suatu ciri, karakter, sifat, model, atau gambaran tentang kondisi, strategi penanaman karakter denga cara eksplorasi secara mendalam terhadap program, dan aktifitas yang dilakukan warga di SDIT Permata Hati.

Penelitian ini dilaksanakan di kota Jayapura provinsi Papua yaitu di Sekolah Dasar Islam Terpadu (SDIT) Permata Hati yang terletak di jalan raya Abepura No. 3A Entrop kota Jayapura provinsi Papua. Sumber data yang digunakan dalam penelitian ini terdiri dari dua bagian, yakni; sumber data primer dan sekunder. Data primer diperoleh langsung dari narasumber melalui wawancara, sedangkan data sekunder diperoleh dari selain data primer. Teknik pengumpulan data dalam penelitian ini menggunakan teknik pengumpulan data seperti berikut: (1) Observasi, (2) wawancara, (3) dokumentasi. Dalam teknik analisa data menggunakan analisa deskriptif kuantitatif, karena data yang diperoleh berupa kata-kata yang dinyatakan dalam narasi yang bersifat deskriptif mengenai peristiwa yang real dilapangan.

Adapun tahap-tahap analisis data menggunakan model Miles dan Huberman. (1) Pengumpulan data. Pengumpulan data adalah proses pengumpulan data mentah dimulai dengan memahmi fenomena yang diteliti, (2) reduksi data, yakni proses pemilihan, pemusatan perhatian pada penyederhanaan, pengabstrakan, transformasi data kasar yang muncul dari catatan-catatan lapangan. Data yang direduksi memberikan gambaran yang lebih jelas tentang pengamatan serta mempermudah peneliti untuk mencari kembali data yang diperoleh. (3) Display data, yakni sajian kalimat yang disusun secara logis dan sistematis. (4) penarikan kesimpulan dan verifikasi data, yakni upaya mencari kesimpulan dari masalah yang diteliti. Pada tahap ini kegiatan yang dilakukan adalah memberikan kesimpulan terhadap data-data hasil penafsiran. Verivikasi yakni menguji kebenaran, kekokohan dan mencocokan maknamakna yang muncul dari kata.

\section{Hasil dan Pembahasan}


Pendidikan karakter menjadi program prioritas di SDIT Permata hati, dimana SDIT Permata Hati berdiri dan berkembangan di kota Jayapura yang masyarakatnya heterogen (plural). Dalam pendidikan karakter pada anak usia sekolah dasar di lingkungan yang homogen dan heterogen jelaslah berbeda. Selain masyarakat heterogen, di kota Jayapura yang maroritas penduduknya berkarir, sedikit pola asuhnya anak terbengkalai. Anak sering ditinggal kerja orang tuanya sehingga pendidikan kurang diperhatikan. Anak berinteraksi dengan temannya dan lingkungan tanpa ada batas dan pengawasan dari orang tua. Dengan fenomena ini, maka dibutuhkan strategi-strategi khusus dalam menanamkan karakter pada anak di lingkungan yang heterogen.

Dari hasil penelitian ada berapa strategi penanaman karakter pada siswa di SDIT Permata Hati kota Jayapuya, yakni pertama Perencanaan. Perencanaan merupakan proses penyusunan suatu yang akan dilaksanakan untuk mencapai tujuan yang telah ditentukan. Perencanaan tersebut dapat disusun berdasarkan kebutuhan dalam jangka waktu tertentu sesuai dengan keinginan pembuatan perencanaan, namun yang lebih penting adalah yang dibuat harus dapat dilaksanakan dengan mudah dan tepat sasaran agar kualitas dalam melakukan pembelajaran dapat terlaksana, sehingga dapat menghasilkan pembelajaran yang optimal (Rahman, 2012). Perencanaan Di SDIT Permata hati dibuat oleh kepala sekolah, guru dan komponen-kompenen yang lainya. Perencanaan ini mencangkup proses pembelajaran, program kegiatan sehari-hari, kerjasama dengan orang tua siswa dan program-progam sekolah. Kemudian dituangkan dalam SOP dan aturan kelas serta disosialiasikan kepada seluruh warga sekolah dan orang tua siswa.

Kedua, Pelaksanaan. Pelaksanaan dalam proses penanaman karakter merupakan interaksi semua komponen yang ada di sekolah dengan siswa guna mencapai tujuan yang telah ditentukan. Dalam pelaksanaan dapat dilakukan dalam proses pembelajaran atau di luar pembelajaran dalam bentuk suatu program yang telah ditentukan sebelumnya. Perencanaan yang matang, tidak akan bisa terwujud kalau tidak ada pelaksanaan. Pelaksanaan yang dimaksud disini adalah melaksanankan beberapa program yang telah ditentukan atau direncanakan sebelumnya dalam perencanaan. Langkah awal dari pelaksanaan ini adalah mensosialiasikan program-program yang telah dibuat kepada guru, staf, orang tua dan pihakpihak yang terkait dengan program-program tersebut. Pelaksanaan penanaman karakter kepada siswa di SDIT Permata hati terbagi menjadi empat bagian; (1) pelaksanaan dalam proses pembelajaran, Proses Pembelajaran. Pembelajaran pada dasarnya merupakan upaya untuk mengarahkan siswa ke dalam proses belajar, sehingga mereka dapat memperoleh tujuan belajar sesuai dengan apa yang diharapkan (Mulyono, 2012). Strategi pembelajaran dapat diartikan upaya pendidik untuk merancang suatu pembelajaran guna mencapai tujuan yang ingin dicapai. SDIT Permata Hati adalah sekolah dasar yang menerapkan pembelajaranya dengan pendekatan pembelajaran terpadu. Pembelajaran di SDIT Permata Hati dengan memadukan pendidikan aqiyah, ruhiyah dan jasadiyah. Artinya SDIT Permata Hati berupaya mendidik siswa menjadi anak yang berkembang kemampuan akal dan intelektualnya, meningkatkan kualitas keimanan dan ketakwaan kepada Allah SWT, terbina akhlak mulianya dan memiliki kesehatan dan keterampilan dalam kehidupan sehari-harinya. Dengan proses islamisasi dalam proses pembelajaran diharapkan terbentuk kesadaran dan pola pikir yang integral dalam perspektif Islam. 
Dengan menggunakan pembelajaran terpadu yang mengaitkan semua materi pelajaran dengan nilai-nilai keislaman akan memudahkan untuk memberikan pemahaman kepada siswa. Sehingga proses penanaman karakter di SDIT Permata hati tidak hanya tanggung jawab guru PAI, tetapi semua pihak yang terkait didalamnya. Menurut fogary sebagaimana dikutip oleh Ahmad Susanto dengan pembelajaran terpadu memungkinkan serta untuk ilustrasi pembelajaran yang dapat mencapai beberapa target konsep yang ada dalam beberapa mata pelajaran (Susanto, 2013).

Pada proses pembelajaran ada tiga tahap yang ada di SDIT permata hati, yakni (a) kegiatan awal yang berisi; guru membuka kegiatan dengan mengucapkan basmallah, menyapa siswa mengkondisikan siswa; guru menyampaikan rencana pembelajaran atau tujuan pembelajaran, (b) kegiatan inti yang berisi kegiatan pembelajaran dengan menggunakan pendekatan PAKEMI (Pembelajaran Aktif Kreatif Menyenangkan dan Islami), (c) kegiatan penutup yang berisi guru bersama siswa merefleksi pembelajaran yang telah selesai serta menutup pembelajaran dengan ucapan hamdallah.

Dari paparan diatas dapat, kita ketahui bahwa proses pembelajaran di SDIT Permata Hati menggunakan pembelajaran terpadu yang diintegrasikan dalam nilai-nilai kesislaman. Dimana semua pelajaran diintegrasikan dalam nilai-nilai Islam semaksimal mungkin. Dalam pengamatan peneliti, peneliti melihat kurikulum SDIT Permata Hati selain menggunakan kurikulum dari kemendiknas juga menggabungkan dengan kurikulum dari JSIT (Jaringan Sekolah Islam Terpadu). Sehingga terlihat silabus dan RPP di SDIT Permata Hati, semuanya ada unsur-unsur keislamannya. (2) pelaksanaan dalam kegiatan sehari-hari. Dalam penanaman karakter di SDIT Permata Hati, salah satunya dengan pengintegrasian nilai-nilai karakter di kegiatan siswa dan guru sehari-hari. Di SDIT Permata Hati dalam pengintegrasian nilai-nilai karakter dalam kegiatan sehari-hari.

Dalam menanamkan karakter pada siswa yang terintegrasi dalam kegiatan sehari-hari dapat dilakukan dengan berbagai strategi, diantaranya Pembiasaan. Pembiasaan harus dimulai dan ditanamkan sejak kecil dan dilakukan secara terus menerus dan konsisten. Karena anak kecil memiliki rekaman ingatan yang cukup kuat dan kondisi kepribadian yang belum matang, sehingga mereka mudah terlarut dalam dengan kebiasaan-kebiasaan yang mereka lakukan setiap hari. Nilai-nilai karakter yang tertanam melalui pembiasaan akan termanifestasikan dalam kehidupannya semenjak ia mulai mengijak usia remaja dan dewasa.

Pembiasaan-pembiasan di SDIT Permata Hati dilakukan semenjak siswa masuk kelas 1 sampai kelas 6. Pembiasan di SDIT bersifat terus menerus sampai mereka lulus. Di SDIT Permata hati siswa dibiasakan untuk mengucapkan kalimat-kalimat thoyibah dalam keseharianya, seperti mengucapkan salam ketika bertemu guru atau teman, atau saat masuk dan keluar kelas, berdoa sebelum dan sesudah makan, berdoa sebelum dan sesudah belajar, mengucapkan istigfar ketika melakukan kesalahan, selain di biasakan untuk mengucapkan kalimat-kalimat thoyibah mereka juga dibisakan membaca al-Qur'an, puasa sunah hari Kamis, berinfak setiap hari Jum'at. Selain itu mereka juga dibiasakan untuk berkata baik, sopan santun kepada siapa saja, tidak menyontek saat ulangan, tidak mengambil barang milik orang lain sebelum dapat izin, berkata jujur, meminta izin ketika masuk dan keluar kelas, pulang tepat waktu, tertib dalam berseragam, disiplin dan sebagainya.

Pembiasaan yang diterapkan di SDIT Permata Hati sejalan apa yang disampaikan oleh Imam Suprayogo, bahwa pembiasaan itu perlu dibiasakan secara sosiologis, perilaku 
seseorang tidak lebih dari hasil pembiasaan saja (Suprayogo, 2004). Oleh karena itu, siswa harus dibiasakan dengan hal-hal yang baik sesuai dengan nilai-nilai karakter yang dipelajarinya. Misalnya, mengucapkan salam ketika bertemu teman maupun guru, membaca doa ketika akan memulai mkan dan mengakhiri makan, membaca basmallah ketika memulai belajar dan mengahiri dengan hamdallah dan sebagainya.

Adapun syarat yang harus dilakukan dalam menerapkan stategi pembiasaan dalam pendidikan adalah: (a) Mulailah pembiasaan itu sebelum terlambat. Di SDIT Permata Hati, pembiasaan dilakukan sejak siswa masuk di SDIT Permata Hati atau semenjak kelas 1. Sejak kelas 1 siswa sudah dibiasakan hal-hal yang positif sesuai ajaran agama Islam. Kebiasaankebiasaan yang positif akan muncul sesuai lingkungan yang membentuknya; (b) Pembiasaan hendaknya dilakukan secara kontinyu, teratur dan terprogram, sehingga pada akhirnya akan terbentuk kebiasaan yang utuh, permanen dan konsisten. Pembiasaan di SDIT di dukung dengan adanya program-program yang dibuat SDIT dan pengawasan oleh guru-guru serta dilakukan secara kontinyu sampai mereka lulus. Oleh pencapaian keberhasilan dari proses pembiasaan ini; (c) Pembiasaan hendaknya diawasi secara ketat, konsisten dan tegas. Jangan memberikan kesempatan yang luas kepada warga sekolah untuk melanggar kebiasaan yang telah ditanamkan. Pembiasaan di SDIT Permata Hati selalu diawasi oleh guru-gur atau wali kelas, apabila melanggar maka guru akan mengingatkan dan menasehatinya. Untuk memperkuat pembiasaan-pembiasaan itu dibuat aturan-aturan tertentu yang mengikatnya; (d) Pembiasaan yang pada mulanya hanya bersifat mekanistis, hendaknya secara berangsurangsur dirubah menjadi kebiasaan yang tidak verbalistik dan menjadi kebiasaan yang disertai dengan kata hati warga sekolah itu sendiri.

Selain pembiasaan strategi berikutnya adalah Keteladanan. Keteladaan sangat penting dalam dunia pendidikan, karena keteladanan dapat merealisasikan tujuan pendidikan dengan memberikan contoh keteladanan yang baik bagi siswa agar mereka dapat berkembang baik fisik maupun mentalnya dan memiliki karakter yang baik dan benar. Bila kita cermati historis pendidiakan di zaman Rasulullah dapat dipahami bahwa salah satu faktor keberhasilan beliau berdakwak atau menyebarkan agama Islam salah satunya adalah dengan keteladanan (uswah). Dalam al-Qur'an keteladaan dijelaskan dalam Q.S al-ahzab ayat 21, Allah berfirman "Sesungguhnya telah ada pada (diri) Rasulullah itu suri teladan yang baik bagimu (yaitu) bagi orang yang mengharap (rahmat) Allah dan (kedatangan) hari kiamat dan dia banyak menyebut Allah". Pendidik atau guru sebagai figur di mata siswanya, apa yang dilihat atau apa yang didengar dari seorang guru bisa ditiru siswa. Untuk itu keteladan guru sangat berpengaruh dalam penanman karakter siswa. Menurut (Ulwan, 1999) keteladanan adalah faktor yang penting dalam menentukan baik dan buruknya anak.

Keteladanan adalah salah satu strategi di SDIT Permata Hati dalam menanamkan karakter kepada anak. Keteladanan di SDIT permata hati sangat ditekankan, oleh sebab itu setiap pekan, guru-guru diberi pembinaan dan evaluasi. Keteladanan yang dilakukan di SDIT Permata hati adalah dengan memberikan contoh-contoh yang baik kepada siswa baik dilakukan oleh kepala sekolah, guru maupun staf kependidikan. Secara kualitas karakter guru di SDIT Permata Hati cukup baik dan bisa dijadikan sebagai tauladan oleh siswa. Hal ini dibuktikan salah satu wali murid menyatakan bahwa karakter guru-guru SDIT luar bisa, sangat patut dicontoh oleh guru-guru lainnyan. Perilaku guru-guru SDIT Permata Hati selalu ada pengawasan dan pengontrolan dari pihak lembaga. Selain itu perilaku guru-guru SDIT 
Permata Hati terbentuk karena adanya pembiasaan dan pelatihan-pelatiahan serta pembinaan setiap seminggu sekali.

Berdasarkan penjelasan diatas maka dapat disimpulkan bahwa dalam penanaman karakter pada siswa sekolah dasar dapat menggunakan strategi keteladanan, dengan berasumsi bahwa karakteristik siswa yang mudah meniru dan mencontoh hal-hal yang disenanginya atau yang diidolakannya membuat strategi ini sangat efektif digunakan dalam menanamkan karakter kepada siswa. Hal ini diperkuat oleh teori Bandura, bahwa dalam teori modeling yang dikemukakan oleh Bandura, manusia belajar mengamati dan menirukan perilaku orang lain. Peniruan model menjadi unsur penting dalam belajar. Individu dapat saling mengajarkan dengan cara saling mengamati perilaku individu yang lainya.

Strategi berikutnya adalah Pengkondisian lingkungan. Lingkungan diartikan segala sesuatu yang berada di luar individu siswa yang memberikan pengaruh terhadap perkembangan dan pendidikan. Pengkondisian lingkungan yang dimaksud disini adalah lingkungan sekolah. Lingkungan sekolah memegang peran penting untuk memenuhi kebutuhan dan merupakan kelanjutan dari pendidikan di lingkungan keluarga. Lingkungan sekolah harus mendukung dalam penanaman karakter siswa. Untuk menciptakan lingkungan sekolah yang kondusif harus dibangun secara bersama-sama oleh semua warga sekolah sesuai dengan fungsi dan kedudukan masing-masing.

Dalam menciptakan lingkungan yang kondusif di sekolah dibutuhkan suatu peraturan. Peraturan-peraturan di sekolah antara lain memuat hak, kewajiban, sangsi, penghargaan baik untuk siswa, guru kepala sekolah atau warga sekolah lainya. Peraturan di sekolah harus mencerminkan karakter warga sekolah. Selain itu dalam penciptaan lingkungan yang positif menurut Achmad Sultoni dapat dilakukan melalui ditegakkannya peraturan sekolah yang mengarah pada penciptaan kebiasaan yang positif di sekolah. Selain itu, kebiasaan positif yang sifatnya rutin seperti mengucapkan salam, berdoa di awal dan akhir pembelajaran, serta upacara dilakukan.

Lingkungan di SDIT Permata hati didesain sebaik mungkin guna mewujudkan lingkungan sekolah yang kondusif dalam aspek agama, kesehatan, kebersihan, suasana kekeluargaan, fasilitas belajar dan ibadah. Prasarana dan sarana di lingkungan SDIT permata hati juga sanga memadahi dalam penanaman karakter siswa. Dilihat dari budaya sehari-hari, dilingkungan SDIT Permata hati tampak budaya keislamannya. Banyak aktifitas-aktifitas, perilaku sesuai dengan ajaran-ajaran agama Islam, baik dari segi perkataan, perbuatan dan lain sebagainya. Penciptaan/ pengkondisian lingkungan dalam penanaman karakter sangatlah penting, hal ini sesuai dengan pendapat dari Haidir Lubis yang menyatakan bahwa penciptaan (milieu) lingkungan sangat penting agar berpengaruh positif dalam pendidikan karakter siswa, seperti melalui penugasan, pembiasaan, pembiasaan, pelatihan, pengajaran, pengarahan dan keteladanan.

Hal ini senada dengan yang di deskripsikan dalam penelitian Haidir Lubis bahwa pendidikan karakter pada tingkatan institusi mengarah pada pembentukan budaya sekolah dan kebiasaan keseharian yang merupakan ciri khas sekolah tersebut. Seperti setiap hari tertentu keberhasilan lingkungan, setiap Senin upacara bendera, setiap pagi menghafal AlQur'an dan lain-lain (Lubis, 2016).

Strategi yang berikutnya dalam penanaman karakter di SDIT Permata hati adalah Menjalin kerjasama dengan orang tua siswa. Keberhasilan dalam menanamkan karakter 
kepada siswa tidak cukup dari pihak sekolah, tetapi harus ada dukungan dari orang tua. Penanaman karakter siswa tidak hanya menjadi tanggung jawab sekolah, tetapi peran dari keluraga juga mempengaruhi. Apabila pembiasaan di sekolah tidak diberengi dengan pembiasaan dirumah, maka siswa akan kembali terpengaruh dengan lingkungan sekitar. Siswa tidak akan bisa terbiasa berakhlak mulia bila tidak ada dorongan dan pengawasan orang tua di rumah. Untuk itu kerjasama antar sekolah dan orang tua sangat penting, karena keduanya akan saling memberikan informasi tentang perkembangan siswa. Kerjasama antara guru dan orang tua merupakan kunci sukses dalam penanaman karakter siswa.

Dalam menjalin hubungan sekolah dengan orang tua, pertama kali yang dilakukan kepala sekolah SDIT Permata Hati adalah membuat kesepakatan bersama dengan orang tua tentang bagaimana kita bekerjasama dalam rangka mendampingi siswa. Apabila orang tua kurang aktif dalam program yang telah ditetapkan sekolah bagi orang tua akan kami kenakan sangsi dan program ini selalu kami evaluasi, jadi kita tahu mana orang tua yang aktif dan mana orang tua yang tidak aktif.

Untuk menjalin komunikasi dengan wali murid di SDIT Permata Hati, menggunakan beberapa cara, diantaranya adalah (1) Melalui buku penghubung, grup WA dan SMS/ Telp. Buku penghubung adalah sarana komunikasi wali murid dan wali kelas. Dalam pengamatan peneliti, buku penghubung ini berisi tentang data siswa, kolom aktifitas di sekolah, catatan harian, aktifitas ibadah. Dari buku penghubung ini wali murid akan dapat mengetahui, aktifitas anak disekolah, catatan harian anak, aktifitas ibadah anak dan informasi-informasi penting lainnya. Sedangkan wali kelas akan memperoleh aktifitas anak di rumah dan ibadah di rumah juga. Apabila buku penghubung kurang efektif maka akan di informasi-informasi yang penting akan di sampaikan lewat gruf Wa, SMS maupun telepon. (2) Pertemuan rutin sebulan sekali dan pertemuan wali murid saat buka puasa. Pertemuan rutin ini dilakukan biasanya dilakukan sebuan sekali yaitu pada hari Sabtu. Agenda dari kegiatan ini adalah parenting orang tua dan rapat orang tua yang membahas tentang perkembangang siswa di sekolah. Selain hari Sabtu, orang tua juga dipertemukan kembali pada saat berbuka puasa.

Adapun strategi terakhir dalam penanaman karakter di SDIT adalah Program Sekolah. Pengitegrasian dalam kegiatan yang diprogramkan terlebih dahulu dibuat perencanaan atas nilai-nilai karakter yang ingin diintegrasikan dalam program-program tertentu. Ada beberapa program yang dibuat SDIT Permata hati dalam menanamkan karakter siswa, diantaranya (1) Majelis Pagi. Majelis pagi dilaksanakan setiap hari setelah sholat Dhuha. Adapun isi dari kegiatan majelis pagi, setiap harinya berbeda-beda. Setiap hari Senin dan Selasa majelis pagi berupa kegitan one days 1 ayat, hari Rabu dan Kamis berupa dzikir al-Ma'tsurat sedangkan hari Jum'at disi dengan kegiatan infaq day dan bersih diri.

One 1 days 1 ayat diadakan guna untuk membiasakan siswa membaca al-Qur'an. Menurut peneliti kebiasaan membaca al-Qur'an di SDIT Permata hati sudah menjadi kebiasan oleh guru maupun siswanya. Pendidikan al-Qur'an juga menjadi salah program unggulan di SDIT dengan menggunakan metode UMMI. Dzikir al-Ma'trurat diajarkan kepada siswa SDIT Permata Hati guna membiasakan siswa untuk berdzikir, mengingat Allah, mengucapkan kalimat-kalimat thayibah. Al-Ma'tsurat adalah salah satu dzikir yang dikarang oleh Sayid Hasan al Banna. Kegiatan infaq day dan bersih diri dilakukan di SDIT Permata hati, mengajarkan siswa untuk gemar berbagi, shodakoh sementara bersih diri di hari Jum'at memberikan pelajaran kepada anak, tentang kesunahan memotong kuku di hari Jum'at serta 
memberikan pemahaman tentang kerapian diri, pentingnya menjaga kesehatan. (2) Majelis Siang. Majelis siang adalah majelis yang diadakan setelah sholat dzuhur. Setelah mereka selesai sholat dzuhur dan berdoa maka aktifitas selanjutnya adalah mendengarkan ceramah atau materi-materi yang disampaikan oleh gurunya, terkait dengan materi-materi keislaman serta memberikan nasehat, motivasi kepada siswanya.

Materi yang disampaikan sesuai dengan SKL yang telah dibuat, contohnya memberikan materi-materi keislamaan terkait penguatan aqidah dan adab adab islami. (3) Personality class atau bina diri islami. Program ini dilakukan jam 10.00 atau sebelum pulang pada hari Jum'at. Dalam program personality class wali kelas memberikan materi-materi tambahan diluar pelajaran terkait dengan keislaman. (4) mentoring. Mentoring adalah salah satu program diluar jam sekolah yang digunakan untuk pembentukan karakter siswa. Model kegiatannya, yakni ngaji bareng, ada materi yang disampaikan mentor (ustadnya). Mentoring ini biasa perkelompok, setiap kelompok terdiri dari 7-10 siswa. Mentoring di SDIT dilakukan mulai dari kelas 1 sampai kelmas 6 sedangkan materinya disesuaikan dengan tingkat kemampuan siswa. (5) sholat dhuha dan dzuhur berjama'ah. Program ini dilakukan guna siswa terbiasa sholat dengan benar, sholat tepat waktu dan mengetahui manfaat dari sholat berjama'ah. (6) Program puasa sunah hari Kamis dan buka bersama. Program bertujuan untuk melatih siswa dalam berpuasa dan mengajarkan puasa-puasa sunnnah selain itu dalam buka bersama ada serangkaian agenda, yakni tempat silaturahim antar orang tua dan wali kelas, ada ceramahceramah sbagai penguat karakter siswa yang disampaikan oleh ustad-ustad pilihan.

Berdasarkan penjelasan tersebut dapat dipahami, bahwa upaya-upaya dalam menanamkan karakter pada siswa SDIT permata hati sesuai dengan pendapat Abdur Rahman yang menyatakan bahwa untuk membentuk manusia memiliki moral baik (good moral person) bukanlah suatu yang tiba-tiba. Ia memerlukan suatu proses panjang yang memerlukan tahaptahap, ia membutuhkan suatu kondisi yang memungkinkan seseorang individu berperilaku sebagai sosok yang memiliki moral yang diharapkan (moral action). Karenanya, ia memerlukan suatu pembiasan (habituation) yang dalam pembiasaan itu secara implisit terhadap adanya keteladanan (modelling). Karena itu diperlukan kerjasama secara integratif dari semua komponen baik sekolah, keluarga maupun masyarakat untuk menciptakan lingkungan yang membiasaakan perilaku anak (Rahman, 2012).

Keterpaduan dan singkroniasi antara nilai-nilai karakter yang diterima siswa melalui proses pembelajaran dengan didorong pengamalan/ pembiasaan dalam bentuk tindakkan dan perilaku yang nyata sehari-hari, tidak hanya siswa sendiri melainkan semua warga sekolah serta didukung dari kerjasama dari orang tua yang proaktif dengan sekolah maka hal ini akan memudahkan dalam membentuk/ menanamkan karakter pada siswa. Sebagaimana pendidikan akhlak (karakter) yang dilakukan di Pesantren Anak-anak Nur Mamba'ul Hisan. Dalam pesantren ini menerapkan totalitas pendidikan dengan mengandalkan keteladanan, penciptaan lingkungan dan pembiasaan melalui berbagai tugas dan kegiatan. Sehingga seluruh apa yang dilihat, didengar, dirasakan dan dikerjakan oleh santri adalah pendidikan. Selain menjadikan keteladanan sebagai metode pendidikan yang utama, penciptaan miliu juga sangat penting. Lingkungan pendidikan itulah yang ikut mendidik. Penciptaan lingkungan dapat dilakukan melalui keteladan, pembiasaan, pemberian tugas, pelatihan, pengajaran dan pengarahan (Subekti, 2015). 
Ketiga, Evaluasi. Evaluasi atau penilaian adalah suatu usaha untuk memperoleh berbagai informasi secara berkala, berkesimbungan dan meyeluruh tentang proses penanaman karakter pada siswa SDIT Permata Hati. Adapun tujuan evaluasi ini adalah untuk mengukur seberapa jauh nilai-nilai yang dirumuskan sebagai standar minimal yang telah dikembangkan dan ditanamkan di sekolah, serta dihayati, diamalkan, diterapkan dan dipertahankan oleh siswa dalam kehidupan sehari-hari. Untuk mengukur keberhasilan pelaksanaan penanaman karakter pada siswa melalui beberapa langkah, yakni (1) menetapkan indikator dari nilai-nilai yang disepakati, (2) menyusun berbagai istrumen penilaian, (3) melakukan pencatatan terhadap tercapainya indikator, (4) melakukan analisis dan evaluasi, (5) melakukan tindak lanjut.

Adapun mekanisme dan prosedur evaaluasi/ penilaian di SDIT Permata hati sebagai berikut (1) Sekolah melakukan perencanaan pencapaian atau target yang ingin dicapai, melalu (a) Membuat rincian indikator dalam penanaman karakter, (b) Merancang strategi untuk mencapai indikator-indikator yang telah ditetapkan, (c) Menetapkan penanggung jawab di setiap bidang/ program, (d) Merancang dan mengembangkan instrumen penilaian; (2) Guru melakukan pengamatan dan pengukuran terhadap indikator yang telah dibuat; (3) Melakukan tindak lanjut berupa perbaikan dan peningkatan program dan strategi pencapaian indikator; (4) Melaporkan hasilnya kepada kepala sekolah dan orang tua.

\section{Kesimpulan}

Berdasarkan uraian di atas dapat kita simpulkan bahwa strategi penanaman karakter pada siswa dapat dilakukan melalui tiga tahap, yakni bagaimana penanaman karakter pada siswa direncanakan (Planning), dilaksanakan (actuating) dan dikendalikan (evaluation). Planing merupakan keseluruhan proses pemikiran penentuan semua aktifitas yang akan dilakukan dalam menanamkan karakter kepada siswa. Adapun perencanaan ini mencangkup proses pembelajaran, program kegiatan sehari-hari, kerjasama dengan orang tua siswa dan programprogam sekolah. Apabila perencanaan telah dibuat maka perlu adanya tindakan atau pelaksanaan (actuating). Dalam melaksaankan perencanaan dalam proses penanaman karakter pada siswa SDIT Permata hati dengan menggunakan strategi pembelajaran, pembiasaan, keteladanan dan kemitraan. Kemudian langkah terakhir pelaksanaan dalam penanaman karakter dievaluasi keberhasilannya. Adapun indikator keberhasilan dalam proses penanaman karakter adalah siswa mempunyai kebiasaan yang sesuai dengan aqidah yang lurus dan akhlak yang mulia.

\section{Daftar Pustaka}

Adisusilo, S. (2013). pembelajaran Nilai-Nilai Karakter. Jakarta: Raja Grafindo Persada.

Efendi, D. (2019). Proses Pembentukan Aqidah dan Akhlak Pada Siswa Sekolah Dasar di Kota Jayapura. Al-Adzka: Jurnal Ilmiah Pendidikan Guru Madrasah Ibtidaiyah, 9(1), 9. https://doi.org/10.18592/aladzkapgmi.v9i1.2814

Febriyanto, dkk. (2020). Pendidikan Karakter dan Nilai Kedisiplinan Peserta Didik di Sekolah. Jurnal Elementaria Edukasia, 3(1).75-81.

Lickona. (1991). Educating for characher. How our school can teach respect and responsibility. New York: Batan Book. 
Lubis, H. (2016). Strategi Penanaman Pendidikan Karakter berkelanjutan pada Anak di Sekolah. Jurnal Pendidikan Islam Tazkiya, 2.

Mulyono. (2012). Strategi Pembelajaran: Menuju Efektifitas Pembelajaran di Abad Global. Malang: UIN-Maliki Press.

Nata, A. (2011). Perspektif Islam Tentang Strategi Pembelajaran. Jakarta: Kencana.

Rahman, A. (2012). Pembiasaan sebagai Basis Penanaman Nilai-Nilai Akhlak Remaja. Jurnal Nadwa, 1.

Samani, M., \& Hariyanto. (2013). Pendidikan Karakter. Bandung: Rosdakarya.

Sanjaya, W. (2008). Strategi Pembelajaran Berorientasi Standar Proses Pendidikan. Jakarta: Kencana.

Subekti, Y. A. (2015). Pendidikan Karakter di Pondok Pesantren Anak-Anak. Ta'limuna, 8.

Suprayogo, I. (2004). Pendidikan Berparadiqma Al-Qurlan (Pergulatan Membangun Tradisi dan aksi Pensisikan Islam. Malang: UIN-Maliki Press.

Susanto, A. (2013). Teori Belajar Dan Pembelajaran Di Sekolah Dasar (Vol. 49). Jakarta: Prenadamedia Grup.

Ulwan, A. N. (1999). Pendidikan Anak dalam Islam. Jakarta: Pustaka Amani. 